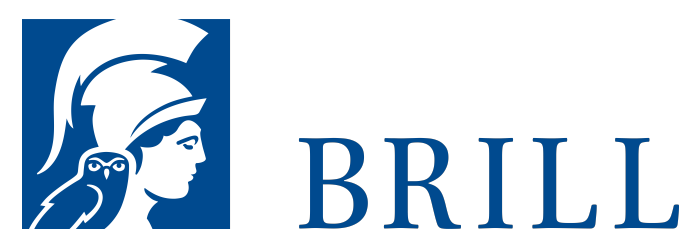

\title{
Rechtfertigungslehre und Gerechtigkeit Gottes in den ökumenischen Dialogen mit russisch-orthodoxer Beteiligung
}

Author: Christoph Mühl

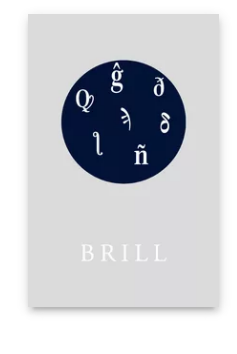

Language:

German

Subjects:

General,

Theology and

World

Christianity

Publisher: Brill |

Fink

Series:

Kulturen der

Gerechtigkeit,

Volume: 7

E-Book (PDF)

Released online:

3o Sep 2024

ISBN: $978-3-$

8467-5550-1

Paperback

Publication date:

30 Sep 2024

ISBN: 978-3-

7705-5550-5 
For more information see brill.com

Order information: Order online at brill.com +44330 333 0049 | customerservices@brill.com Submission information: brill.com/authors

Titles published by Brill | Fink, Brill | mentis or Brill | Schöningh: +49(o)715413279216| brill@brocom.de 